\title{
Application of the Eluate Method of Phytotesting in Assessing the Waste Toxicity of the Process of Chemical Oxidation of Metals
}

\author{
Angelina Moiseeva $^{1(D)}$, Vitaly Kuksanov ${ }^{1(D)}$, Olga Chekmareva ${ }^{1}$ (D), Alina Baitelova ${ }^{1(D)}$, \\ Ludmila Bykova ${ }^{1, * \text { iD }}$ \\ 1 Orenburg State University, 13, pr. Pobedy, Orenburg, 460018, Orenburgskaya oblast, Russia \\ * Correspondence: bykovaludmila@yandex.ru (L.B.);
}

Scopus Author ID 57197807237

Received: 15.05.2021; Revised: 12.06.2021; Accepted: 15.06.2021; Published: 24.06.2021

\begin{abstract}
The work describes the use of the eluate method of phytotesting in determining the toxic properties of waste from the metal chemical oxidation process. The experiment used two test cultures: radish (Raphanus sativus) and oat (Avena sativa L.) that showed the same toxicity results of studied samples. According to the established method, the research was carried out, mathematical models of the dependence of the phytoeffect on waste dilution were predicted, the safe waste dilution was calculated, and the results of the studies concluded on the classification of the risk of the waste under study.
\end{abstract}

Keywords: protective coating; chemical oxidation; waste; eluate phytotesting.

(C) 2021 by the authors. This article is an open-access article distributed under the terms and conditions of the Creative Commons Attribution (CC BY) license (https://creativecommons.org/licenses/by/4.0/).

\section{Introduction}

Environmentally-friendly production, which means the balance is maintained, and there is no contradiction between its development and the protection of the environment, should be a priority in the work of all branches of business. Today, to develop production sustainably, it is necessary to take into account the quality and value of produced products and services and pay special attention to its environmentally friendly producing process [1-5].

One of the most pressing environmental issues is the large-scale formation of industrial waste and the solution to their recycling. Thus, in Russia, the mass of waste production and consumption from manufacturing activities in 2017 was 274816.8 thousand tons/year, and in 2019, this parameter increased to 296442.6 thousand tons/year [6-11].

All production processes are sources of both chemical and physical impact on the environment. In the processing of metals, there are used a huge variety of chemicals change the properties of metals, increase their persistence, hardness, corrosion protection, and application of decorative coatings. A wide range of items of used organic compounds, alkalis, and acids inevitably leads to the formation of wastes extensive on the list and of various hazard classes [12-16].

To protect the metal from oxidation in mechanical engineering, there are very often used technologies such as oxidation (thermal, chemical, electrochemical), anti-corrosion coating (based on zinc), organic-silicate coating, phosphatization, paint coating, etc. [17-19]. At each stage of these technologies, toxic waste is produced, the dangerous properties of which 
are not fully understood and, therefore, there is no complete picture of their impact on the environment and specifically on humans.

The work aims to determine the degree of toxicity of waste from the cleansing of the tank for chemical oxidation of details (further "studied waste") by the method of eluate phytotesting [20-25].

In order to achieve the result according to our goal, the following tasks were solved:

- conducting a literary review of the chemical oxidation process;

- sampling for the study;

- studying the samples on toxicity with the selected method;

- analysis of the findings.

\section{Materials and Methods}

To obtain a protective, anti-corrosion coating of metal, an oxidation process is used. The methods of applying an oxide film can be classified by:

1. The way of applying:

- thermic,

- chemical,

- electrochemical;

2. The environment in which the process takes place:

- water steam,

- mineral oil,

- vegetable oil,

- molten salts,

- alkaline solution.

The thermal oxidation method is where the metal is heated in the air or the water steam environment at $450-650^{\circ} \mathrm{C}$ with a pressure of $0.3 \mathrm{~atm}$, resulting in the formation of a protective film of up to 10 microns [26,27]. The anti-corrosion properties of the oxide film in this method of application have high rates, although when the temperature of processing decreases, there is also a tendency to reduce the protective properties of metal. The thermal oxidation technology is carried out in an electric pit-type heating furnace.

To apply a protective film on the surface of the metal, the method of chemical oxidation (acid and alkaline ones) has become more widespread. Suppose it is necessary to create a protective film thinner than 3 microns.

Table 1. Compositions of chemical oxidation solutions

\begin{tabular}{l|l|l|l|l|l|l|l}
$\begin{array}{l}\text { Compositions of } \\
\text { solutions (g/l) and } \\
\text { conditions }\end{array}$ & $\mathbf{1}$ & $\mathbf{2}$ & $\mathbf{3}$ & $\mathbf{4}$ & $\mathbf{5}$ & $\mathbf{6}$ & $\mathbf{7}$ \\
\hline $\begin{array}{l}\text { The temperature of } \\
\text { solutions, }{ }^{\circ} \mathrm{C}\end{array}$ & $135-155$ & $135-145$ & $138-142$ & $136-138$ & $125-135$ & $135-155$ & $137-145$ \\
\hline $\mathrm{NaOH}$ & $600-700$ & $650-700$ & $600-650$ & $650-700$ & $500-600$ & $700-800$ & $600-700$ \\
\hline $\mathrm{NaNO}_{3}$ & - & $650-700$ & $100-200$ & $30-35$ & $50-100$ & $75-125$ & $120-160$ \\
\hline $\mathrm{NaNO}_{2}$ & $200-250$ & $200-250$ & - & $15-18$ & $50-100$ & $75-125$ & $120-160$ \\
\hline $\mathrm{NaCl}^{\mathrm{Na}} \mathrm{PO}_{4}$ & - & - & - & $18-20$ & - & - & - \\
\hline
\end{tabular}

In that case, alkaline oxidation will be used, where the process occurs in the solutions of nitrites or nitrates of sodium, potassium, or caustic alkali. The protective layer on the surface 
of metals thinner than 5 microns is achieved by acid oxidation, which flows in a solution of phosphoric acid, calcium, barium nitrate [28]. The compositions of chemical oxidation solutions are represented in Table 1 [29]. The alkaline oxidation occurs when iron interacts with alkaline in the presence of an oxidizer by reaction 1 .

$$
\mathrm{Fe}+\mathrm{O}+2 \mathrm{NaOH}=\mathrm{Na}_{2} \mathrm{FeO}_{2}+\mathrm{H}_{2} \mathrm{O}
$$

The electrochemical oxidation technology occurs in less concentrated alkaline solutions and at a lower temperature than in chemical oxidation. Despite the fact, the metal coating has higher protective properties with this method. However, with all the positive aspects of this technology, the electrochemical oxidation of metals has not been widely used in the industry because of the complexity of the process since it requires the application of special pendent devices and to ensure a source of direct current [30].

The testing of metal on the anti-corrosion resistance proved that the highest protective properties had oxide films obtained by the thermal method in the heated steam environment, followed by electrochemical and chemical oxidation methods (reducing protective properties) [31].

The oxidation technology line consists of the following sequential processes that are carried out in individual tanks: degreasing of details, washing, chemical oxidation, oiling.

As a result of the chemical oxidation technology, waste is generated after each tank is cleaned. To address the issue of waste disposal, it is necessary to know its toxic properties.

S.S. Vinogradov, in his research [32,33], introduces the concept of "Ecological Criterion (EC)", which is defined as the ratio of the concentration of a harmful substance in waste to its MPC.

$$
E C=\mathrm{C}_{\text {conc }} /{ }_{M P C_{\text {soil }}}
$$

Suppose there are several harmful substances in waste. In that case, the end result of the "Ecological Criterion" is equal to the sum of their ratios. In environmentally friendly production, the EC should be less than or equal to 1. Thus, in the work of S.S. Vinogradov [34], the values of the environmental hazard of solutions used in the technologies of forming protective coatings on metal are calculated (Table 2).

Table 2. Environmental hazard of solutions [34].

\begin{tabular}{l|c} 
Technology operation & Environmental hazard, $\mathbf{1 0}^{\mathbf{6}}$ \\
\hline Chemical degreasing & $0.002 \div 10$ \\
\hline Chemical oxidation of aluminum and its alloys & $0.1 \div 0.3$ \\
\hline Chemical oxidation of magnesium alloys & $0.4 \div 2.7$ \\
\hline Chemical oxidation of steel & $1.8 \div 2.1$ \\
\hline Phosphatizing of steel & $0.3 \div 3.8$
\end{tabular}

Environmental hazard values show potential hazards to the environment and may indicate the toxicity of the used solutions. Table 2 states that the solutions used in applying protective coatings on metals pose an environmental hazard to the environment and, accordingly, the waste from the production cycle has similar properties. 


\section{Results and Discussion}

Toxic properties of waste were determined considering the following composition of oxidation tanks:

- sodium nitrate GOST 828-77 (50-70 g/l);

- sodium nitrite GOST 19906-74 (200-250 g/l);

- caustic soda GOST P 55064-2012 (700-800 g/l) [3, 10].

To determine the toxic properties of the studied waste, we selected the method of eluate phytotesting according to the method MR 2.1.7.2297-07 "Substantiation of the hazard class of production and consumption waste by phytotoxicity".

The eluate phytotesting method in research accurately determines the degree of toxic and bioactive properties, the hazard class, and the level of harmless waste dilution. The waste hazard criteria are presented in Table 3.

Table 3. Hazard criteria of waste [35]

\begin{tabular}{l|l|l|l|l} 
Class & $\mathbf{1}$ & $\mathbf{2}$ & $\mathbf{3}$ & $\mathbf{4}$ \\
\hline Hazard rating & Extremely hazard & Highly hazard & Moderately hazard & Low-hazard \\
\hline ER$_{50}$ & $>100$ & $10>100$ & $1>10$ & $\leq 1$
\end{tabular}

Before the beginning of the experiment, all seeds were tested for germination (at least $95 \%$ ), then the seeds were germinated ( 25 pieces) in Petri dishes on filter paper under the introduction of the extract of the waste dilutions as the medium. Each concentration of waste was duplicated three times [11-17]. The duration of the experiment was 7 days at $21^{\circ} \mathrm{C}$ (Figure $1)$.

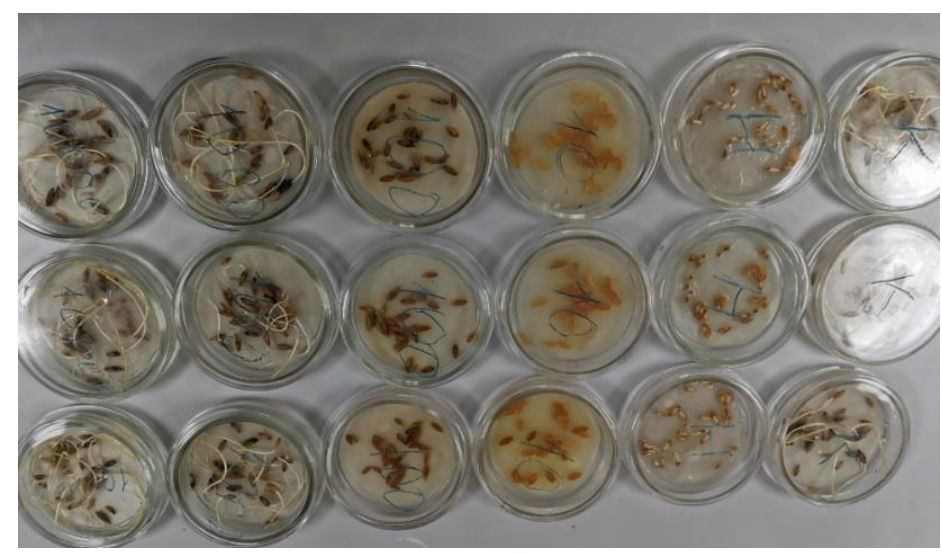

Figure 1. Eluate phytotesting of the waste.

At the end of the exposure period, lengths of the test crops' roots were measured, which is shown in Tables 4 and 5.

Table 4. The root lengths of the test plant oat (Avena sativa L.) under the eluate phytotesting of the waste.

\begin{tabular}{l|l|l}
$\begin{array}{l}\text { Dilution } \\
\text { extract }\end{array}$ & Root length, mm & $\begin{array}{l}\text { Average } \\
\text { length, mm }\end{array}$ \\
\hline 1 & $0,0,0,0,0,0,0,0,0,0,0,0,0,0,0,0,0,0,0,0,0,0,0,0,0$ & 0 \\
\hline 10 & $0,0,0,0,0,0,0,0,0,0,0,0,0,0,0,0,0,0,0,0,0,0,0,0,0$ & 0 \\
\hline 100 & $0,0,0,0,0,0,0,0,0,0,0,0,0,0,0,0,0,0,0,0,0,0,0,0,0$ & 0 \\
\hline 1000 & $50,46,52,49,45,49,51,47,47,54,41,59,48,44,53,52,45,49,59,41,52,54$, & 49 \\
& $47,41,43$ & \\
\hline 10000 & $90,99,105,87,104,110,112,101,107,80,85,92,103,110,89,90,105,98$, & 100 \\
& $104,79,105,112,96,115,120$ & \\
\hline Control & $114,90,119,85,94,101,99,115,107,87,93,111,106,102,90,104,119,96$, & 103 \\
& $94,120,105,100,95,107,110$ &
\end{tabular}


Table 5. The root lengths of the test plant radish (Raphanus sativus L) under the eluate phytotesting of the waste

\begin{tabular}{l|l|l}
$\begin{array}{l}\text { Dilution } \\
\text { extract }\end{array}$ & Root length, mm & $\begin{array}{l}\text { Average } \\
\text { length, mm }\end{array}$ \\
\hline 1 & & \multicolumn{1}{c}{ root } \\
\hline 10 & $0,0,0,0,0,0,0,0,0,0,0,0,0,0,0,0,0,0,0,0,0,0,0,0,0$ & 0 \\
\hline 100 & $0,0,0,0,0,0,0,0,0,0,0,0,0,0,0,0,0,0,0,0,0,0,0,0,0$ & 0 \\
\hline 1000 & $0,0,0,0,0,0,0,0,0,0,0,0,0,0,0,0,0,0,0,0,0,0,0,0,0$ & 0 \\
& $25,19,15,10,21,24,9,14,18,10,14,22,27,12,11,16,26,9,21,7,15,23,18$, & 17 \\
\hline 10000 & 21,10 & \\
& $54,39,41,61,57,54,49,40,62,44,36,31,53,61,64,47,58,53,42,60,48,63$, & 50 \\
\hline Control & $47,51,39$ & \\
& $60,45,47,61,53,43,45,60,40,54,57,49,44,35,54,58,63,48,42,39,48,53$, & 50 \\
& $61,40,41$ &
\end{tabular}

The inhibition of seed germination was calculated by formula 3:

$$
\mathrm{E}_{I}=\frac{L_{C}-L_{E X}}{L_{C}} \times 100 \%
$$

where $\mathrm{E}_{\mathrm{I}}$ - the inhibition effect, \%; LEX - average root length in the experiment, $\mathrm{mm}$; $\mathrm{LC}_{\mathrm{C}}-$ average root length of the control, $\mathrm{mm}$.

The results of the effect of the studied waste on the seeds of oat and radish are summarized in Tables 6 and 7.

Table 6. Effect of the studied waste on the seeds of oat

\begin{tabular}{l|l|l|l|l} 
Dilution of extract & $\begin{array}{l}\text { Average root length, } \\
\text { mm }\end{array}$ & $\begin{array}{l}\text { Average root length } \\
\text { \% to the control }\end{array}$ & Phytoeffect, \% & Reaction \\
\hline Control & 103 & 100 & 0 & typical \\
\hline 10000 & 100 & 97.1 & 3 & $\begin{array}{l}\text { minor } \\
\text { effect }\end{array}$ \\
\hline 1000 & 49 & 47.6 & 52.4 & inhibiting \\
\hline 100 & 0 & 0 & 100 & death of seeds \\
\hline 10 & 0 & 0 & 100 & death of seeds \\
\hline $\begin{array}{l}1 \\
\text { (native) }\end{array}$ & 0 & 0 & 100 & death of seeds
\end{tabular}

Table 7. Effect of the studied waste on the seeds of radish

\begin{tabular}{l|l|l|l|l} 
Dilution of extract & $\begin{array}{l}\text { Average root length, } \\
\text { mm }\end{array}$ & $\begin{array}{l}\text { Average root length } \\
\text { \% to the control }\end{array}$ & Phytoeffect, \% & Reaction \\
\hline Control & 50 & 100 & 0 & typical \\
\hline 10000 & 50 & 100 & 0 & typical \\
\hline 1000 & 17 & 34.0 & 66.0 & inhibiting effect \\
\hline 100 & 0 & 0 & 100 & death of seeds \\
\hline 10 & 0 & 0 & 100 & death of seeds \\
\hline $\begin{array}{l}1 \\
\text { (native) }\end{array}$ & 0 & 0 & 100 & death of seeds
\end{tabular}

Results of the studies reveal that $100 \%$ of the seeds of both test crops die at the dilution of waste 1:100; at the concentration of 1:1000, there is an inhibiting effect, and when diluted 1:10000, there is the normal development of seeds. Figure 2 illustrates the phytoeffect of the seed development inhibition at different concentrations of waste dilution. 


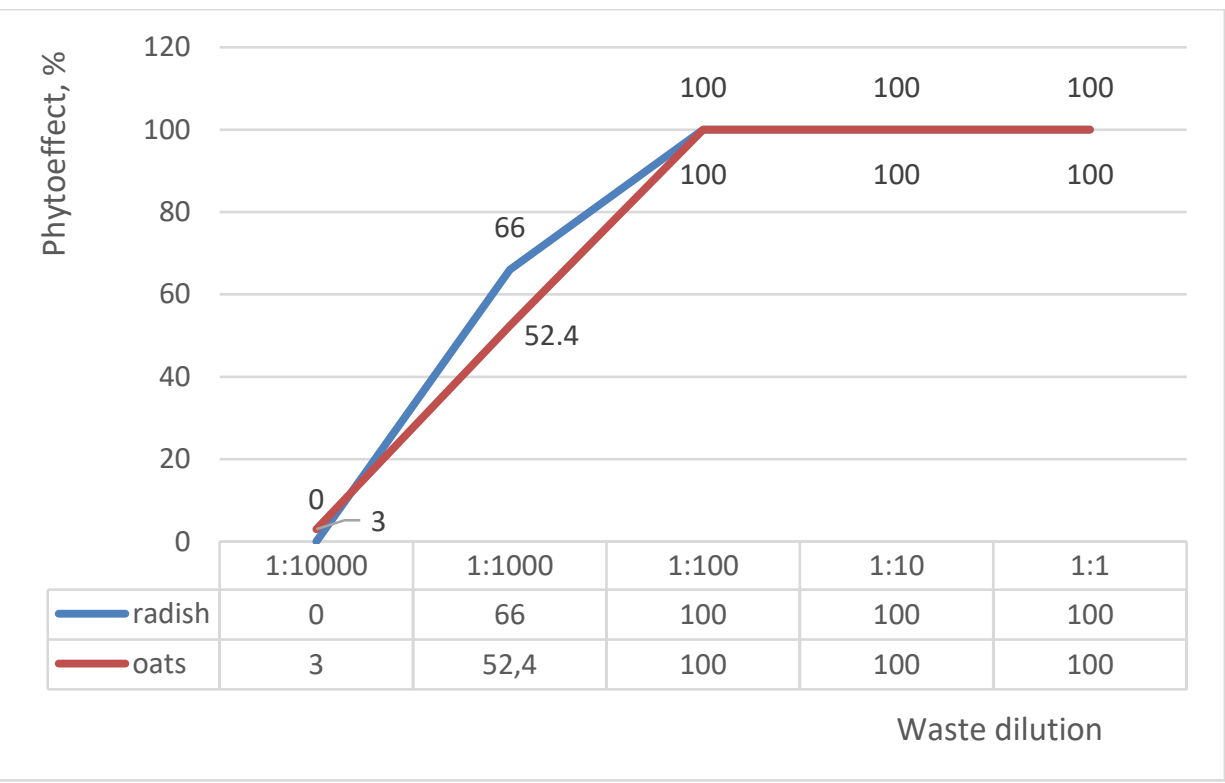

Figure 2. Seed development inhibition at different dilutions of waste.

Further, taking into account the direct dependence of the phytoeffect and the dilution of waste, we will predict the mathematical models in the form of regression equations.

The mathematical model of the impact of waste on oat seeds:

$$
\lg R=-0.032 E_{I}+4.29
$$

The mathematical model of the impact of waste on radish seeds:

$$
\lg R=-0.031 E_{I}+4.26
$$

The mathematical models are formulated adequately, as indicated by the following correlation coefficients:

- 0.88 - for the oat test-plant;

- 0.85 - for the radish test plant.

The mathematical models provided graphs of dependency $\operatorname{lgR}=\mathrm{f}(\mathrm{ET})$ (Figures 3, 4).

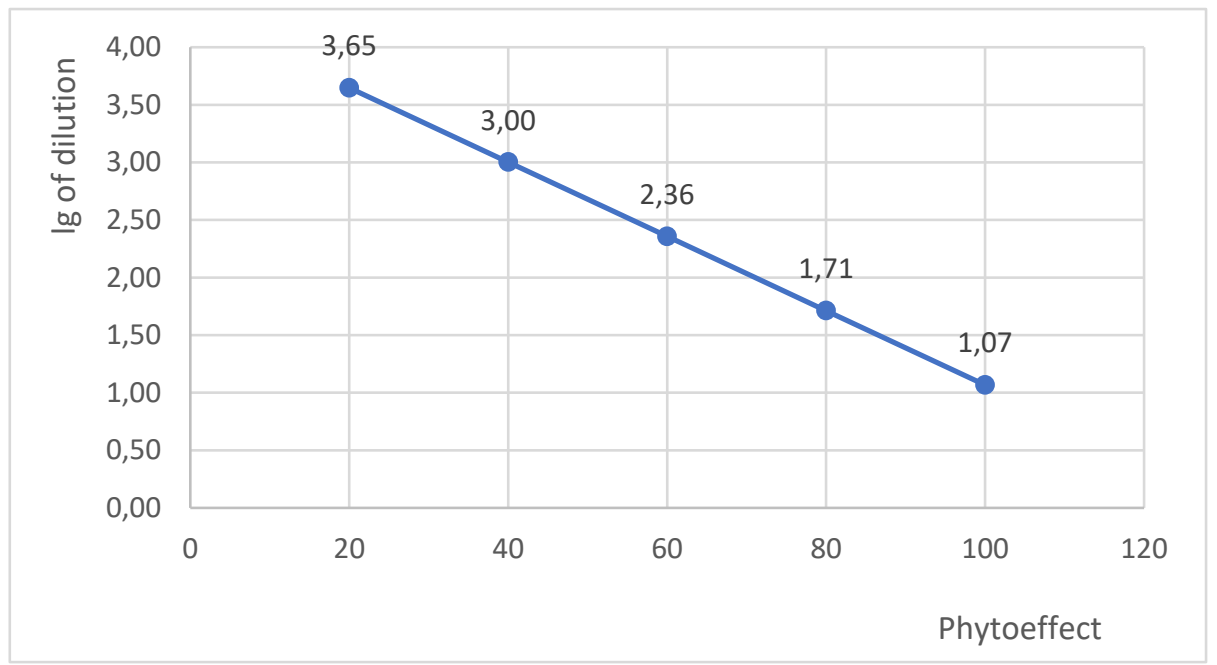

Figure 3. Chart of the impact of waste on oat seeds. 


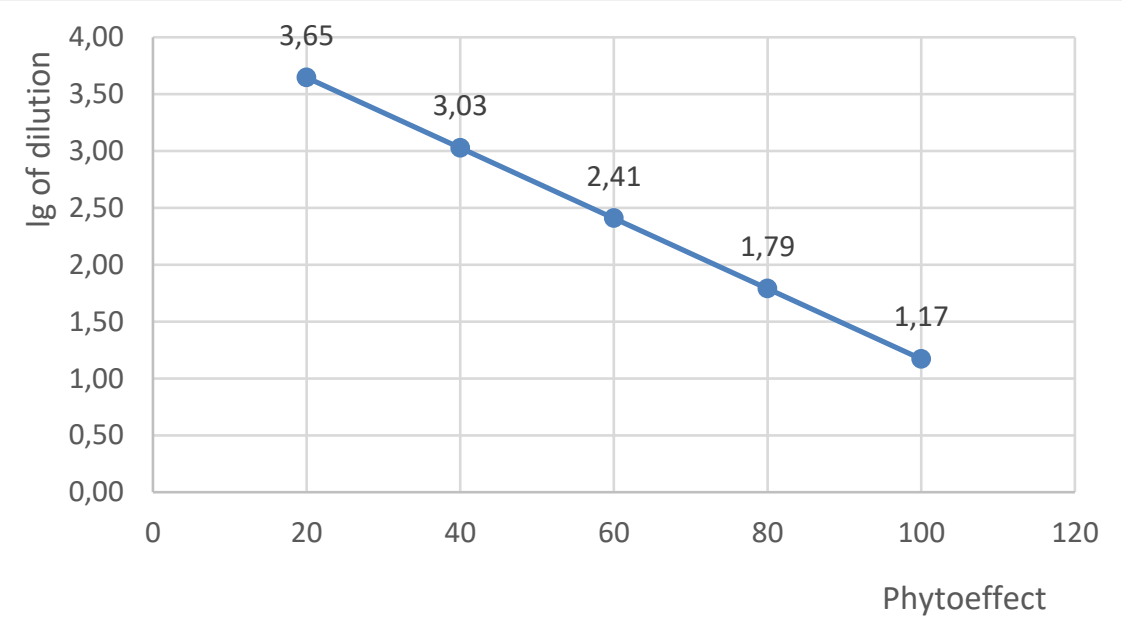

Figure 4. Chart of the impact of waste on radish seeds.

The hazard class of the waste was determined by the average effective dilution (when the phytoeffect equals 50\%). In the case of oat, this figure was 478.3 and 522 for the test culture radish.

Thus, according to Table 3, it was proven on two test plants that the waste understudy is extremely hazardous.

Previously, the authors of the work investigated the toxic properties of waste using a bio testing method using test crops Scenedesmus quadrcauda and Daphnia magna $[17,18]$ and the method of contact bio testing [19-22]. All previous studies and experiments described in this article indicate the hazardous properties of waste from metal surface processing by chemical oxidation. Therefore, a comprehensive decision on the disposal of this waste is needed.

Thus, in biotesting with the use of test objects Daphnia magna and Scenedesmus quadrcauda, there were observed more than $50 \%$ of Daphnia magna test organisms when diluting the study sample of waste in ratios of $1: 1 ; 1: 100 ; 1: 1000$. When using the test object Scenedesmus quadrcauda, the death of more than $50 \%$ of alga cells was detected at concentrations of $1: 1,1: 100,1: 1000$, indicating that the waste sample belongs to the Class II of hazard [23].

In the contact laboratory study of waste in the cleansing of the tank for processing metal surfaces by the method of the chemical oxidation, toxic properties of waste are observed at the dilution concentrations of 1:1, 1:5, 1:10, 1:50, 1:100, both on the length of the sprout and the root.

\section{Conclusions}

The method of eluate phytotesting helped determine the degree of toxicity of waste from the cleansing of the tank for chemical oxidation of details. Thus, when the phytoeffect equaled 50\%, the average effective dilution for oat (Avena sativa L.) was 478.3 and 522 for the test culture radish (Raphanus sativus $L$ ). These findings prove that understudy waste is extremely hazardous.

The studies provide a complete picture of the dangers of metal surfaces' chemical oxidation for both humans and the natural environment. Further studies need to determine the composition of the waste for addition in the federal waste classification catalog (FWCC) [24] and decide how it should be disposed of or utilized. 


\section{Funding}

This research received no external funding.

\section{Acknowledgments}

The authors express their gratitude to the Department of Ecology and Nature Management of Orenburg State University and in particular to the head of the Department of Ecology and Nature Management of Glukhovskaya Marina Yuryevna for providing the laboratory and laboratory equipment for conducting research.

\section{Conflicts of Interest}

The authors declare no conflict of interest.

\section{References}

1. Al Souki, K. S.; Liné, C.; Louvel, B.; Waterlot, C.; Douay, F.; Pourrut, B. Miscanthus x giganteus culture on soils highly contaminated by metals: Modelling leaf decomposition impact on metal mobility and bioavailability in the soil-plant system. Ecotoxicol Environ Saf. 2020, 199, 110654, https://doi.org/10.1016/j.ecoenv.2020.110654.

2. Talaybekova, G.T.; Kozhobaev, K.A.; Tokpaeva, Zh.K.; Esenzhanova, G.K.; Totubaeva, N.E. Phytotesting of oil-contaminated soils using phytolerant plants. Problemy regoinalnoy ecologii 2019, 2, $20-24$ (In Russia).

3. Kuryntseva, P.A. Combined processing of organic industrial, municipal and agricultural waste by anaerobic digestion and composting. PhD Thesis, Lobachevsky State University of Nizhny Novgorod, 23, Prospekt Gagarina (Gagarin Avenue), BLDG 2, 2nd floor, Nizhny Novgorod, Russia, 2016 (In Russia).

4. Goryachev, A.A.; Krasavtseva, E.A.; Laschuk, V.V.; Ikkonen, P.V.; Smirnov, A.A.; Maksimova, V.V.; Makarov, D.V. Assessment of environmental hazards and the possibility of processing the tails of are enrichment. Ekologiya i promyshlennost Rossii 2020, 24, 46-51 (In Russia).

5. Kuksanov, V.F.; Moiseeva, A.A.; Chekmareva, O.V. Assessment of waste toxicity from the chemical oxideing process of metals. Ekonomika stroitelstva i prirodopolzovaniya 2019, 3, 76-82 (In Russia).

6. Kuryntseva, P.A.; Vybornova, I.B.; Galitskaya, P.Yu.; Selivanovskaya, S.Yu. Changing the toxicological characteristics of the pyro-coal from the chicken droppings in the process of chemical modification. Uchenye zapiski Kazanskogo universiteta. Seriya: Estestvennye nauki 2019, 161, 77-92 (In Russia).

7. Moiseeva, A.A.; Kuksanov, V.F.; Chekmareva, O.V. Assessment by contact method of phytotesting of waste toxicity from part carbonitation technology and subsequent oxidation. Ekonomika stroitelstva $i$ prirodopolzovaniya 2020, 2, 116-124 (In Russia).

8. Sassanelli, C.; Rosa, P.; Rocca, R.; Terzi, S. Circular economy performance assessment methods: A systematic literature review. Journal of Cleaner Production 2019, 229, 440-453, https://doi.org/10.1016/j.jclepro.2019.05.019.

9. Singh, N.; Duan, H.; Ogunseitan, O.A.; Li, J.; Tang, Y. Toxicity trends in E-Waste: A comparative analysis of metals in discarded mobile phones. Journal of Hazardous Materials 2019, 380, https://doi.org/10.1016/j.jhazmat.2019.120898.

10. Shrader-frechette, K.S.; Biondo, A.M. Protecting children from toxic waste: Data-usability evaluation can deter flawed cleanup. International Journal of Environmental Research and Public Health 2020, 17, https://doi.org/10.3390/ijerph17020424.

11. Tong, L.; He, J.; Wang, F.; Wang, Y.; Wang, L.; Tsang, D.C.W.; Tang, Y. Evaluation of the BCR sequential extraction scheme for trace metal fractionation of alkaline municipal solid waste incineration fly ash. Chemosphere 2020, 249, https://doi.org/10.1016/j.chemosphere.2020.126115.

12. Kundelchuk, O.P.; Skok, S.V.; Gridasov, E.R. Evaluation of the influence of technogenic night lighting on living organisms by methods of phytotesting. Taurian Scientific Herald 2020, 1, 207-214, https://doi.org/10.32851/2226-0099.2020.116.1.28.

13. Bardina, T.V.; Bardina, V.I. Environmental control of the borrow soils of careers in the territory of the cleanage of the neva river by methods of phytotesting. Proceedings of the Russian State Hydrometeorological University 2019, 54, 91-99, https://doi.org/10.33933/2074-2762-2019-54-91-99. 
14. Selyanina, S.B.; Ponomareva, T.I.; Yarygina, O.N.; Trufanova, M.V.; Zubov, I.N. Biologically active components of peat of the arctic zone of Russian federation. Khimiya Rastitel'nogo Syr'ya 2020, 1, 293-301, https://doi.org/10.14258/jcprm.2020014626.

15. Eremchenko, O.Z.; Pakhorukov, I.V. assesment of the ecological condition of salted, acid and alkaline soils by the phytotesting method. Bulletin of Perm University. Biology 2019, 1, 63-71, https://www.researchgate.net/publication/335994319_ASSESMENT_OF_THE_ECOLOGICAL_CONDITI ON_OF_SALTED_ACID_AND_ALKALINE_SOILS_BY_THE_PHYTOTESTING_METHOD.

16. Wang, J.; Shih, Y.; Wang, P.Y.; Yu, Y.H.; Su, J.F.; Huang, C.P. Hazardous waste treatment technologies. Water Environment Research 2019, 91, 1177-1198, https://doi.org/10.1002/wer.1213.

17. Xiong, Z.; Zhang, H.; Zhang, W.; Lai, B.; Yao, G. Removal of nitrophenols and their derivatives by chemical redox: A review. Chemical Engineering Journal 2019, 359, 13-31 https://doi.org/10.1016/j.cej.2018.11.111.

18. Dzidziguri, E.L.; Sidorova, E.N.; Yahiyaeva, J.E.; Ozherelkov, D.Y.; Gromov, A.A.; Nalivaiko, A.Y. Lowtemperature oxidation of metal nanoparticles obtained by chemical dispersion. Micro and Nano Letters 2020, 15, 461-464, https://doi.org/10.1049/mnl.2019.0706.

19. Krasavtseva, E.A.; Maksimova, V.V. Application of the phytotesting method to assess the environmental impact of the waste of Lovozersky GOK LLC. In IOP Conference Series: Earth and Environmental IOP Publishing Ltd. 2020, 548, https://doi.org/10.1088/1755-1315/548/6/062063.

20. Sushkova, S.; Minkina, T.; Dudnikova, T.; Barbashev, A.; Mazarji, M.; Chernikova, N.; Kizilkaya, R. Influence of carbon-containing and mineral sorbents on the toxicity of soil contaminated with benzo[a]pyrene during phytotesting. Environmental Geochemistry and Health 2021 https://doi.org/10.1007/s10653-02100899-x.

21. Kravsun, T. Phytotesting of heavy metal contamination of Donbass soils. Diversity of Plant World. 2020, 3 , 37-44, https://doi.org/10.22281/2686-9713-2020-3-37-44.

22. Fomina, N. V. Phytotesting and environmental assessment of soil in the greenhouse complex. In IOP Conference Series: Earth and Environmental Science. 2020, 548, https://doi.org/10.1088/1755$1315 / 548 / 2 / 022081$.

23. Krasavtseva, E. A.; Maximova, V. V.; Masloboyev, V. A.; Makarov, D. V.; Gorbacheva, T. T. Modeling the interaction of the fine fraction of loparite ore mill tailings with soil waters. Ecology and Industry of Russia. 2021, 25, 28-33, https://doi.org/10.18412/1816-0395-2021-4-28-33.

24. Pastushenko, Ya.; Kundelchuk, O.; Sidorovich, M. Determination of the effect of boiling on the biological properties of tap water by means of phytotesting. Naukovì Dopovidì Nacional'nogo Universitetu Bioresursiv ì Prirodokoristuvannâ Ukraïni. 2020, 6, https://doi.org/10.31548/dopovidi2020.06.002.

25. Cherniak, L.; Mikhyeyev, O.; Madzhd, S.; Oksana, L.; Tetyana, D. \& Valentyna, P. Determination of the Dependence of the Plant Growth Characteristics on the Concentration of Petrochemicals in the Soil. Journal of Ecological Engineering. 2021, 22, 226-233, https://doi.org/10.12911/22998993/131063. 